\title{
Paideusis
}

\section{A Taxonomy of Responses and Respondents to Literature}

\section{Deanne Bogdan}

Volume 1, Number 1, 1987

URI: https://id.erudit.org/iderudit/1071143ar

DOI: https://doi.org/10.7202/1071143ar

See table of contents

Publisher(s)

Canadian Philosophy of Education Society

ISSN

0838-4517 (print)

1916-0348 (digital)

Explore this journal

Cite this article

Bogdan, D. (1987). A Taxonomy of Responses and Respondents to Literature.

Paideusis, 1(1), 13-32. https://doi.org/10.7202/1071143ar viewed online.

https://apropos.erudit.org/en/users/policy-on-use/ 


\section{A Taxonomy of Responses and Respondents to Literature}

\section{Deanne Bogdan, The Ontario Institute for Studies in Education}

This paper grows out of three of research interests: the philosophical bases of aesthetic/literary response, a developmental approach to the pedagogical treatment of student responses to literature, and the critical theory of Northrop Frye, in whose work the concepts and some of my terminology originates. 1 What follows is a sequel to three papers already published, all dealing with the attempt to analyze and systematize kinds and levels of literary response. ${ }^{2}$

The critical and educational climate which surrounds this study addresses the increasing attention paid to the role of the reader in instantiating the literary text, and to language as the key to cognitive and emotional development. 3 Often theorie and which become "movements" run the risk of imbalance and the creation of false dichotomies, with the result that perfectly valid aspects of doctrines which have gone before become obfuscated and trivialized. For example, reader response criticism comes close to rejecting the very possibility of ontological definitions of the text altogether. Language as learning, if carried to extremes, can become a neo-Deweyan hagiography of the child, which, instead of unleashing students' powers of articulation threatens to plunge them into mute solipsism. In literature education, this kind of polarization takes the form of the popular misconception that literary analysis invariably deals a deathblow to the vitally engaged, spontaneous, and thus authentic response.

\section{Total Form: Stasis}

Paradigmatic of the presumed schism between the intellectual and emotional literary response is the attitude adopted by Michael Caine as the alcoholic English professor in the film Educating Rita, who purports to teach his students the techniques of literary criticism. Rita, eager for both literary experience and literary knowledge, comes to Caine as what Northrop Frye calls "a genuine primitive,"4 that is, one who is ignorant of literary convention. During her first forays into literary experience, Rita undergoes a transformation of consciousness, experiencing the full brunt of Longinian ecstasis. 5 But, lacking the necessary skills, grammar, and vocabulary of criticism, Rita is unable to articulate her experience. 
In the process of educating Rita to literature, Caine chisels her tabula rasa squeals of "Wow!" and "Fantastic!" into polished emanations of "lit. crit." and, in his view, turns his Galatea into a Frankenstein.

Caine hankers

after a state of imaginative identity with the poetic object, typified by the fusion of intellect and emotion in the response of a genuine primitive. But genuine primitives like Rita are really only metaphors for the ideal literary experience, which hardly ever occurs. As a real student of literature, Rita is as vulnerable as the rest of us to misapplications of theory to practice, be they ossified operations of the old philology, abstract exercises of the New Criticism, or pretentious pyrotechnics of the New New Criticism. The very verbalizing of any response to literature must, after all, of itself be an attenuation of the actual experience, and in a sense it is through criticism that we mourn the loss of that intensity. Although I am not a Marxist critic, here I take refuge in Fredric Jameson, who refer to the "painful 'decentering' of the consciousness" entailed in literary response. Like George Steiner, Jameson is wary of the dangers in "nostalgia for the absolute" when he asserts that "the approach to the Real is at best fitful, the retreat from it into this or that form of intellectual comfort perpetual." 6

Rita's "state of imaginative identity with the poetic object" is what I refer to as "stasis". Stasis can be described as the simultaneous perception and experience of the "total form" of a literary work, ${ }^{7}$ however fleeting that glimpse might be. Rita's stasis is a condition which literature teachers usually aim at but rarely succeed in triggering. When it does occur, stasis often takes place unexpectedly and outside the classroom. An intensely personal and private experience perhaps best expressed by silence, it is usually marked by a recession of cognitive faculties and a near paralysis of linguistic powers. 8

Stasis can be thought of as the overcoming of T. S. Eliot's dissociation of sensibility. In his essay, "The Metaphysical Poets," Eliot observes that the English dramatists of the sixteenth century and their successors, the poets of the seventeenth century, "possessed a mechanism of sensibility which could devour any kind of experience." But ever since Milton and Dryden mastered the art of integrating sensibility, language, and feeling became divorced in the history of the English literature. In general, "while the language became more refined, the feeling became more crude," and there grew 
up either sentimentality or cerebration. In the nineteenth century, continues Eliot, we see "traces of a struggle toward unification of sensibility. But Keats and Shelley died, and Tennyson and Browning ruminated." 9

Northrop Frye has modified the concept of dissociation of sensibility to signify the virtual psychological impossibility of simultaneously participating in and being consciously aware of experience. 10 To hope for transcendence of dissociation of sensibility in the teaching of literature comes with the territory; most teachers want students to share in those rare instances wherein sign and signifier are felt as one. In his introduction to Paul de Man's Blindness and Insight: Essays in the Rhetoric of Contemporary Criticism, Wlad Godzich uses the analogy of a flash of lightning to describe

\begin{abstract}
a perfect congruence between the expression and that which is expressed. Lightning cannot be said to be hidden before its manifestation but rather expresses itself... fully in the instant of its illumination. In fact, it suspends the difference between the manifest and manifesting, producing in its instantaneity a moment of perfect presence. 11
\end{abstract}

Moments of perfect presence are spiritual experiences which readers desire to recur. Yet, the dark side of lightning, so to speak, is its brevity and randomness. When applied to reading literature, the lightning model has severe limitations. First, it is simply unreliable; its elusiveness must be counterbalanced and supplemented by the disciplined training of perception, as Godzich notes, "to ensure that lightning does strike.. . and, even more formidably, that it strikes repeatedly, as well, in the same place and with the same intensity."12 Godzich would corroborate Frye's admonition not to trust to "the gambling machine of an ideal [literary] experience"13 but to turn to the training of perception through literary criticism, which makes up for the absence of stasis. Stasis, then, can be taught to but not taught for; that is, teachers may wish to set the stage for stasis, but should not seek to orchestrate the conditions under which it might occur or interfere with its effects. That is what I think Frye means when he says we cannot teach literature, only literary criticism. 14 The literary experience as such is a kind of private property, and when that experience is marked by stasis, the respondent is best left alone.

The kinds of texts which elicit stasis on a first reading are those in which mythos (plot) and dianoia (theme) are so inextricably intertwined that the reader grasps the work holistically and instan- 
taneously as a frozen simultaneous pattern. 15 Short stories such as de Maupassant's "The Necklace" and Sinclair Ross's "The Painted Door" have the kind of clear outline that enables the reader to experience a kind of Aristotelian anagnorisis, or recognition scene ${ }^{16}$ fairly readily in a single participating response. Stasis tends to be most intense when the discovery of the "truth" of the situation by the reader coincides with that of the protagonist, and it is usually accompanied by ironic reversal, as in "The Necklace." 17

Sinclair Ross's "The Painted Door" evokes the same effect. Ann, the wife of a Canadian prairie farmer several years her senior, is left alone during a fierce blizzard by her husband, John, who sets out on foot to assist his father with some chores at his farmhouse, ten miles distant. Hurt by John's allegiance to his filial duty taking precedence over his concern for her, Ann broods about her sense of isolation, the tedium of her marriage, and the steadfast but colourless character of her husband, as she begins to paint their bedroom in order to pass the time. Ann's loneliness and anxiety are assuaged by a visit from Steven, a neighbour and family friend much younger than John. Ann and Steven become aware of their mutual sexual attraction and sleep together, though through the night Ann is wracked with guilt and haunted by the image of John's face. Sick with worry because he has failed to return, Ann realizes too late her deep love for her husband.

Already it was long past midnight; either John had lost his way or not set out at all. And she knew that in his devotion there was nothing foolhardy. He would never risk a storm beyond his endurance, never permit himself a sacrifice likely to endanger her lot of future. They were both safe. No one would ever know. She must control herself - be sane like Steven.

For comfort she let her hand rest awhile on Steven's shoulder. It would be easier were he awake now, with her, sharing her guilt; but gradually as she watched his handsome face in the glimmering light she came to understand that for him no guilt existed. Just as there had been no passion, no conflict. Nothing but the same appraisal of their situation, nothing but the expectant little smile, and the arrogance of features that were different from John's. She winced deeply, remembering how she had fixed her eyes on those features, how she had tried to believe that so handsome and young, so different from John's, they must in themselves be her justification.

In the flickering light, they were still young, still hand- 
some. No longer her justification-she knew now, John was the man-but wistfully still, wondering sharply at their power and tyranny, she touched them a moment with her fingertips again.

She could not blame him. There had been no passion, no guilt; therefore there could be no responsibility. Looking down at him as he slept, half smiling still, his lips relaxed in the conscienceless complacency of his achievement, she understood that thus he was revealed in his entirety - all there ever was or ever could be. John was the man. With him lay all the future. For tonight, slowly and contritely through the days and years to come, she would try to make amends.

Then she stole back to the kitchen, and without thought, impelled by overwhelming need again, returned to the door where the draft was bitter still. Gradually toward morning the storm began to spend itself. Its terror blast became a feeble, worn-out moan. The leap of light and shadow sank, and a chill crept in again. Always the eaves creaked, tortured with wordless prophecy. Heedless of it all the clock ticked on in idiot content.

They found him the next day, less than a mile from home. Drifting with the storm he had run against his own pasture fence and overcome, had frozen there, erect still, both hands clasping fast the wire.

"He was south of here," they said wonderingly when she told them how he had come across the hills. "Straight south-you'd wonder how he could have missed the buildings. It was the wind last night, coming every way at once. He shouldn't have tried. There was a double wheel around the moon."

She looked past them a moment, then as if to herself said simply, "If you knew him, though-John would try."

It was later, when they had left her awhile to be alone with him, that she knelt and touched his hand. Her eyes dimmed, it was still such a strong and patient hand; then, transfixed, they suddenly grew wide and clear. On the palm, white even against its frozen whiteness, was a little smear of paint. 18

This story almost invariably induces stasis as the flash of lightning wherein thought and feeling coalesce. The reader sustains a powerful shock of recognition that John indeed had returned home, and after seeing the two in the bedroom, slipped away back into the 
storm. There results a suffusion of aesthetic pleasure, arising from the immediate impact of dianoia perceived as mythos, and mythos perceived as dianoia. Simultaneity of expression and illumination become both a function and enactment of the interconnection between the reader's feelings and awareness of the author's craft. This is what I would term literary response as "total form."

Earlier I suggested that the clearer the outline of a literary work, the more likely it is to induce stasis; the reason is the importance for literary experience of recognition or discovery as a true shock, and is contingent upon a certain aesthetic distance. That is, while there should be sufficient verisimilitude for the reader to "identify" with the characters, place, and situation (we must, after all, care about what happens), there must also be a real sense of separation from the world of routine experience to enable the work to be perceived as an aesthetic artifact, or what Frye calls "an alien structure of the imagination." 19 This point cannot be overstressed. To weaken the reader's capacity for anagnorisis by underplaying the distinction between literature and life augurs ill in the reading of fiction, for often it is not recognized that intensity of impact is directly related to what Aristotle calls the joy of learning that occurs when we compare the imagined construct with the natural reality of "life." 20 Joy of learning becomes aesthetic pleasure when we become aware of the differences between literature and life as well as the similarities. More accurately, pleasure is generated as a consequence of similarity through difference, the difference made by the imposition of literary form on the raw material of life.

Thus efforts to select literary works on the basis of their ready appeal to students" "real life" interests, problems, and experience are often misguided. The social relevance of subject matter and a powerful literary response can make strange bedmates, for the sense of difference from life that is primarily responsible for intensity of impact is mitigated by "a subcritical operation based on plausibility or likelihood" 21 beginning very early in the reading of realistic works. A case in point is John Updike's "A \& $P$ ", a story about a nineteen-year-old grocery clerk who quits his job in protest when three teenage female customers, clad only in bathing suits, are asked by the manager to leave the store.

Stasis is an uncommon literary response in "A \& P." In fact, students tend to dislike the story. 22 One of the reasons they do so, I believe, is the close proximity between the story's action and dialogue to that of average adolescent's "real" experience. Students tend either to overidentify with or be immediately alienated by the snippets of conversation, attitude, and sensibility of the narrator; consequently they perceive the story as unfinished, as "partial form." Stasis, as we have seen, depends upon perception of a work as "total 
form," which the apparent super-realism of "A \& $P$ " works against. On the one hand, the naive reader is likely to become frustrated by the surface incompleteness of the story, simply because as a story its formal outline is obscured by the impulse to look for the kind of obvious coincidence of mythos and dianoia present in works like "The Necklace" and "The Painted Door." In "A \& $P$ " formal outline is secondary to verisimilitude and identification, and the reader, more apt to be what Douglas Vipond and Russell Hunt call "story-driven" or "information-driven" rather than "point-driven," often misses the point on a first reading. 23 On the other hand, the more sophisticated reader will more readily take the point (which may be described as Sammy's passage from the world of innocence to experience), yet the very critical equipment brought to bear on this discovery can attenuate the element of shock in the act of recognition; that is, the story will be seen as a "structure of the imagination" but one not "alien" to people's everyday lives. As a result, Godzich's flash of lightning is less likely to occur. This is not to say that the story fails, but simply to question stasis as a universal measure of literary value. If the incidence of stasis decreases in direct proportion to the resemblance of literature to life, and if the realistic mode continues to attract students and teachers of literature, we must find a model of response other than the flash of lightning upon which to base our criteria for the selection, evaluation and teaching of literary texts.

\section{Partial Form: The Stock, Kinetic, and Spectator Responses}

As the apotheosis of engagement with the total form of a literary work, stasis represents primitive response in bono. Despite its unpredictability and ambiguity in critical and methodological terms, stasis is a psychological state to be prized and luxuriated in even if it is not directly to be sought after. I have already suggested that the neophyte is perhaps more open to stasis than seasoned aficionados of the classics, whose knowledge of literary convention tends to lessen the impact of a direct response. But the naive respondent, lacking the expertise at making fine discriminations between literature and life, is also more vulnerable to primitive response in malo, that is, the stock and kinetic responses. While stasis fuses subject with object, invoking the reader's active cocreation of the text, stock and kinetic response are passive forms of automatic reflex, reinforcing what is already known rather than paving the way for what might be known, stock response with respect to the content of the work, kinetic response with respect to its form. Mistaking the part for the whole, each is mired in partial 
form. Stock and kinetic response (which underlie the psychology of advertising) are the apogee of dissociation of sensibility, stock response thriving on clichéd thought; kinetic response, on pseudofeeling.

Stock response operates less as an authentic reaction to a text than as a projection of the reader's moral and ideological anxieties. What is more, it values them on the same basis, as though one can extract what something says from the way in which it is said. Left to its own teleology, the stock response, harmless enough in a reader who likes Lord of the Flies because of the desire to live alone on an island, culminates in a mob mentality that would burn a book thought to subvert the prevailing ethos. 24

In general, stock response springs from a refusal to suspend belief, from an unwillingness to delay the kind of aesthetic gratification that comes only with the expenditure of effort to perceive total literary form. It is knee-jerk reaction in terms of "I like/dislike it" based on value judgements about the truth or falsity of literary statements as though they applied to "real life" and "real people." It is responding to an "aliterary" decontextualized string of words as opposed to an organic "order of words" $;$ it is response circumscribed by the readily discernible. 26

But what does stock response look like in the reading of particular texts? As suggested earlier, it is usually grounded in either a deficiency or excess of sympathetic identification. In "The Painted Door," it shows up as moral disapproval of Ann's behaviour without imaginative participation in her moral struggle. In "A \& $\mathbf{P}$," it is accepting the story according to whether Sammy, the narrator, reconfirms or countervails readers' preconceptions about events and attitudes as they relate to their own experience or ideological predilections. Consider, for example, the opening paragraph of the story:

In walks these three girls in nothing but bathing suits. I'm in the third checkout slot, with my back to the door, so I don't see them until they're over by the bread. The one that caught my eye first was the one in the plaid green two-piece. She was a chunky kid, with a good tan and a sweet broad soft-looking can with those two crescents of white just under it, where the sun never seems to hit, at the top of the back of the legs. I stood there with my hand on a box of HiHo crackers trying to remember if I rang it up or not. I ring it up again and the customer starts giving me hell. She's one of those cash- register watchers, a witch about fifty with rouge on her cheekbones and no eyebrows, and $I$ know it made her day to trip me up. She'd been watching cash registers for fifty years and probably never seen a mistake before. 27

Paideusis 
On the one hand, positive stock responders, 28 if they are or have been grocery clerks, say they can easily "relate to" Sammy's unabashed people- watching; as a result, they tend to delight in his caricatures of his customers and his contempt for the conformity of his dull community. On the other hand, negative stock responders take an instant dislike to Sammy, identifying with the objects of his sexism and ridicule-the three girls in bathing suits and the "witch about fifty with rouge on her cheekbones and no eyebrows." Many readers reject the story on the basis of what they consider to be trivial or morally reprehensible content, as though Sammy were the boy next door rather than the author's fictive invention. Occasionally, a militant feminist will not read beyond this first paragraph. Others, less socially committed, easily become bored because they regard the story as outdated, the details of contemporary life having changed markedly from the 1950s, when "A \& P" was written.

Whereas stock responders relate literature to life exclusively in terms of their current experience and values, kinetic responders simply want literature to "work" for them on a superficial aesthetic level, as entertainment only. To say that a James Bond thriller induces physiological changes in me is not necessarily to validate it as a literary work of the imagination. If that thriller is a movie, my visceral state probably has more to do with my response to Roger Moore than with the artistry, real or alleged, of the creator of 007 . With respect to "A \& $P$," the kinetic responder views its dialogue and characterization as a kind of TV sitcom "imitation of life," deriving pleasure mainly from an uncritical acceptance of Sammy's "comical" sexist and insulting observations. These responses often take the form of remarks such as, "Updike is so true-to-life, isn't he?" and "Aren't 19-year old boys exactly like that?"

While positive and negative stock responses spring from a faulty sense of sympathetic identification, positive and negative kinetic responses have to do with a limited conception of aesthetic or literary craftsmanship. Negative kinetic responders tend to complain about "A \& $\mathrm{P}$ "'s supposed formal deficiencies, such as a weak plot ("Nothing really happens; it's kind of stupid"); choppiness ("The story is mind-boggling. It jumps from one thing to another a lot"); superfluousness ("There are lots of unnecessary descriptions"); and an "unsatisfying ending" ("the story leaves you out on a limb, and you don't know what happens to the guy that quits, and you don't really find out the girl's reaction to the scene afterwards." ${ }^{29}$ A careful rereading of "A \& $P$ " will, in fact, disclose how Updike has meticulously prepared the reader for the final action.

Two rather more subtle forms of kinetic response involve the reader's own complicity in blocking emotional response; these respon- 
dents fall into two main categories, the predictor and the ideologue. The predictor's literary knowledge is so self-conscious that it truncates response by interposing guessing games between the respondent and the text. It is as though a surfeit of reading in a particular literary mode or genre prompts the reader to jump the gun on the author. Remarks such as, "Not another Updike ending!" or "All these modern rites of passage stories are ironic!" reveal the somewhat jaded predictor. Here the problem is not that response is insufficiently grounded in the text, but that the text remains a static body of words because the reader's feelings are not open to imaginative engagement. With the stock responder, ordinary experience gets in the way of literary experience; with the predictor, literary knowledge militates against literary experience.

Like the stock responder and the predictor, the ideologue is closed to the full literary response because of an entrenched mindset; but with the ideologue, the barrier against the aesthetic mechanism is constructed by extra-literary knowledge or belief systems. For example, an ideologue might respond to "A \& $P$ " negatively primarily because of feminist objections to Sammy's sexism. More sophisticated than both the stock responder or the predictor, the ideologue transcends both the intellectual capriciousness of the former and emotional anaemia of the latter because her response is more likely to be informed by both literary knowledge and a conscious act of the rather than literary naivete and automatic reflex.

The ideologue's major impediment to literary response is a kind of circular argument: the awareness that Sammy's moment of illumination is contingent upon and exploits the uncritical acceptance of sexism as a historical and sociological datum is an informed response that in a sense works against the ideologue's aesthetic pleasure. Such comments as, "How typically male! Sammy's maturation comes at a very high price-the traditional rescue operation of Cinderella by Prince Charming!" reflect a high degree of critical working through of the story; but ultimately it is a process which, rather than pushing back the limits to response, circumscribes it by way of an a priori centring of the consciousness within a closed mythology. When "A \& $P$ " is regarded as just another illustration of the denigration and silencing of women by the patriarchal structure, it threatens to become simply a sociological document delimited by the conditions of time and place of author or reader.

The spectator response can be thought of as the demonic form of the critical act; in general, it is born of the abuse of criticism in the classroom treatment of literary response. Closest to the spectator response is the negative kinetic response, which combines analysis with indifference to the vital inhabiting of other lives and other worlds; but the spectator response is induced by methodological and pedagogical factors rather than by an excess of literary knowledge, so 
to speak. In short, it is teacher-caused through the endless "naming of parts", the unremitting fragmentation of literary works (usually in accordance with the tenets of the now old New Criticism) that so often desiccates a poem or short story in the minds and hearts of the uninitiated. The spectator response heralds the triumph of positivism in the literature class; nothing counts except what can be weighed and measured by mechanical quotation or formula essay. Under the tyranny of the spectator response, literature study ceases to be part of the humanities and becomes indistinguishable from the ugliest excesses of social science. ${ }^{30}$

The spectator response is uncommon in "A \& $P$ " if only because the natural tendency is to read the story in an engaged rather than a detached mode. Nevertheless, the kinds of influences which might conspire to produce the spectator response are those which stem from overzealous teachers who will accept only one interpretation, for example, the story is an expression of an Emersonian individualistic philosophy; from interdisciplinary units of study which are sometimes based upon misconceptions about literature as a historical or social document; or from a single methodology, such as examining the story according to the tenets of I.A. Richards' practical criticism. In these cases response might be reduced to looking for and gathering specific kinds of literary "evidence". The best defence against the spectator response is to became aware of a plurality of critical viewpoints, but always with an eye to engaged reading of the text.

\section{Total Form: Literary Response as Dialectic}

The stock, kinetic, and spectator responses typify those reactions to a literary work that reflect Eliot's dissociation of sensibility: they either sentimentalize or stereotype, and lack truth, or overintellectualize, and lack feeling. As such, they constitute partial form. But dissociation of sensibility is a perfectly normal way of responding to art, at least initially, and we should not devalue its place in the attainment of a full literary response. If the reader is truly a maker of meaning, and if the psyche is really crucial to the reading act, then a literary response without reference to the welter of thoughts and emotions that go to make up the reader's world-view would not only be illogical but undesirable. Literary response as dialectic accepts dissociation of sensibility as a fact of life, and endeavours to actualize the total form of a literary work through the alternation between engagement or the participating response, and detachment or the critical response. Instead of longing for stasis, of trusting to the gambling machine of an ideal experience, the reader turns to literary response as dialectic, which legitimates and capital- 
izes on the responses of partial form by building on whatever emotional and intellectual raw material presents itself at a precritical level in such a way that response can be deepened, refined, and enriched through aesthetic distance. By resisting instant gratification, literary dialectic transcends the impulse to limit response, viewing the literary work neither as an object to be dissected nor an analogue of personal experience, ideas or values, but as a separate reality, an "alien structure of the imagination," a verbal universe whose selfcontainment logically precedes its referential function. Through exploration of the poem as a construct of otherness, as much as a reflection of experience, wants, and desires, the reader comes to recognize the self as part of the larger pattern of the human condition. Thus transformation of consciousness and transformation of literary knowledge are interdependent. Frye expresses this phenomenon in terms of the myth of deliverance:

One begins by reading or seeing a play like other plays, subject to the conditions and limitations of its own age and to our corresponding limitations in receiving it. One ends with the sense of an exploding force in the mind that keeps destroying all the barriers of cultural prejudice that limit the response to it. In other words, we begin with a notion of what the play might reasonably be assumed to mean, and end with realizing that what the play actually does mean is so far beyond this as to be in a different world of understanding altogether. 31

In what follows, I shall attempt to outline briefly the kinds of literary responses to "A \& P" that represent movement from a precritical stage through to what I shall call critical, postcritical, and autonomous stages. (In stasis, the reader passes through these stages simultaneously, much like Plato's mystical lover of beauty in his instantaneous grasp of the Forms.)

Readers pass from the precritical to the critical response in "A \& $P$ " in a number of ways, the simplest being the ability to interpret Sammy as a fictional personage rather than as a young man whose behaviour we approve of or not. In each of the responses below, the readers commit what Frye calls "the centrifugal fallacy;"32 that is, they strive to see the point as a moral or social one, not a specifically literary one.

- I think that the story is not incomplete or pointless. I feel that the point was that bathing suits are not allowed in stores. 
- I liked the story because it shows that there can be something to smile about even in a bad situation.

- I think that maybe Updike was trying to show us the foolishness that young men and women go through trying to impress each other.

- The inner meaning, that I grasped, was the fact that Sammy's job meant nothing to him and how this relates to how others feel about their jobs as well.

- I enjoyed the story and thought it was great for the young generation. Some of us are too headstrong at times and need to be put in our place by other people sometimes. 33

But consider this reaction from a first-year female college student: "I know Sammy is sexist, but that's the way guys are; at least he moves, he acts, he does something different, knowing there might be negative consequences for himself." Here the reader's judgement reflects a willingness to see both sides of the sexism issue; but more than that, it regards the point of the story in literary as well as moral terms with the result that she broadens her own perspective on sexism itself. In order to understand "A \& $P$ " as a rite of passage, this reader has been forced to suspend belief in her own ideology, at least temporarily, enough to accept Sammy first on Updike's terms and to inquire into the elements of craft that make the story work at an archetypal level. By coming to terms with the distinction between literary convention and reality, her views about reality are modified: later she concluded that the Prince Charming archetype, which embodies the rite of passage in this story, shows that males are as much victims of social rituals as females. Here the respondent moved from the critical to the post-critical stage, where the literary interpenetrates with the moral to produce an altered social vision.

A more sophisticated example of the critical and post-critical levels is typified in the response of the graduate student who perceived Updike's foreshadowing of Sammy's heroic gesture in his description of the "clean bare plane of the top of her chest down from the shoulder bones like a dented sheet of metal tilted to the light" (p. 188). Here the narrator uses a classical image of beauty to describe Queenie, the principal object of Sammy's attention, in marked contrast to his flippant stereotype of girls in general ("Do you think it's a mind in there or just a little buzz like a bee in a glass jar?)" (p. 188) immediately preceding his change of tone. This same respondent linked Sammy's quitting his job to Emersonian philosophy in a critical response that proceeded to the postcritical 
relating of literature to life by comparing the Emersonian context of "A \& P" with the Puritan methods of Ross's "The Painted Door" as a way of articulating differences between American and Canadian culture. 34

The autonomous response is intended to represent that aspect of literary dialectic which most closely approximates stasis. Most readers, whether steeped in literature or groping their way through it, lack either the innocence or discipline for stasis, and must be content with one or other forms of dissociation of sensibility as they work their way through the oscillation between engagement and detachment. Sometimes the autonomous response, which affords the greatest coalescence between literary experience and knowledge, is achieved. In one sense, the autonomous response is more valuable than stasis because it is built on the kind of training that keeps the flash of lightning striking in the same way and with the same intensity. 35 The autonomous response may not result in the ideal experience, but it eliminates the gambling machine by bringing stasis to consciousness. Fusing thought, emotion, sensitivity to literary nuance and scrupulous attention to the way in which the literary dimension adjudicates the aesthetic, moral, and social elements in the story, the autonomous response unleashes the psychic energy that refuses to limit response. It begins on the far side of the knowledge that, as Paul de Man has reminded us, sign and meaning can never completely coincide, ${ }^{36}$ and ends with an expansion of insight and a heightened sensibility to art and to life.

What does the autonomous response look like in "A \& $P$ "? Perhaps it can most profitably be viewed within the recurrent issue of the story's sexist overtones. The response that follows is that of a militant feminist, who is propelled beyond her negative stock response to the innocence/experience archetype, but who is still painfully aware of the patriarchal structure that allows the archetype to function. More interested in the creation of new archetypes that would signal the passing of innocence to experience by females in ways very different from Updike's, she nevertheless resists the temptation to negative closure of her response. This respondent could have taken refuge in the notion that aesthetic taste has historically been used against women. Such a statement may well be true. The problem is that as a literary response it becomes its own endpoint.

By contrast, this reader used her literary critical expertise to address the issue of sexism, with quite a different outcome. She noted that the story's sexism devolves upon discriminations of voice, upon how the author modulates Sammy's tone and attitude to create an ironical stance not only between Sammy and the reader, and Sammy and Updike, but Sammy and himself. What this respondent is able to see is Sammy looking down at himself telling the story, 
and with that perception comes a constellation of new possibilities for the sociology of the piece. Author and reader become reunited by the text in a redefinition of Aristotle's thought 37 from the reciprocal set of moral and intellectual assumptions between author and reader/audience to a renewed conception of text. That is, author and reader commune not simply as secret sharers in a particular moral or social ethos but as mutual participants in the realization that literary texts restructure thought processes by violating the expectations of routine existence. For example, if readers can see Sammy himself as a storyteller, conscious of his place in the narrative as narrative, they can peel back the layers of potential indoctrination posed by a sexist closed mythology; they can actually interpret "A \& $\mathrm{P}$ " as the possibility of a new open mythology in gender relations.

As a story progresses, the voices resonating from the narrator become more subtle and complex with Sammy's increasing selfawareness. At the beginning Sammy's voice as narrator is unidimensional: he is telling the story as himself, more or less "straight." As he becomes more involved in the situation, we can almost overhear Updike's voice in his:

"We are decent," Queenie says suddenly, her lower lip pushing, getting sore now that she remembers her place, a place from which the crowd that runs the $A \& P$ must look pretty crummy. Fancy Herring snacks flashed in her very blue eyes (p. 192)

Towards the final movement of the story, Sammy's ironic distance on himself gradually increases, beginning with his selfdesignation as the girls' "unsuspected hero." At the end, the modality of the "sexism" is that of tragic-irony.

I look around for my girls, but they're gone of course. There wasn't anybody but some young married screaming with her children about some candy they didn't get, by the door of a powder-blue Falcon station wagon. Looking back in the big windows, over the bags of peat moss and aluminium lawn furniture stacked on the pavement, I could see Lengel in my place in the slot, checking the sheep through. His face was dark gray and his back stiff, as if he'd just had an injection of iron, and my stomach kind of fell as I felt how hard the world was going to be to me hereafter (p.192).

Sammy knows they were never his "girls" at all, and the sting is gone from his sexist caricature of the "young married."

I(1), Fall, 1987 
The preceding is an example of an autonomous response. Of course, no response or respondent can completely escape social conditioning. The autonomous response, in the sense in which $I$ use it, springs from a recognition of ideological bias in the reading subject and the textual object. It is a response in pursuit of the dialectic of total form by playing literarily, that is, freely and independently, with the text as an open and hypothetical construct. The autonomous respondent understands that the text exists in its whites and its gaps as much as in the words on the page, and that response to the text may reside in the silence of stasis or in the reader's proffered meaning of the word as co-created. Gifted by some measure of simultaneity between engagement and detachment, the autonomous responder is probably not swept away by Plato's "divine madness," but neither is she frozen in a state of rapt wonderment, as Plato tells us, ever gazing upward like a bird, insensible to the world of everyday reality. ${ }^{38}$ Like the Rita of the film, she is ineluctably thrust towards engagement and the irreducible human form of whole experience, while at the same time educated to detachment and the unavoidable truth that meaning is plural. Literature as dialectic, then, lends the best of both worlds of engagement and detachment, providing a basic skill of the imagination that keeps us living our lives with one foot in heaven. 


\section{Notes}

${ }^{1}$ For a discussion of the bases of these categories of response, see Deanne Bogdan, Instruction and Delight: Northrop Frye and the Educational Value of Literature, Diss. University of Toronto, 1980, 290-310.

${ }^{2}$ See Deanne Bogdan, "Pygmalion as Pedagogue: Subjectivist Bias in the Teaching of Literature," English Education, Official Journal of the Conference on English Education, (University of Pittsburgh), 16(2), (May) 1984; Northrop Frye, The Secular Scripture: A Study of the Structure of Romance (Cambridge, Ma.: Harvard University Press, 1976), 131.-75; "Literary Criticism in the Classroom," in Kathleen B. Whale and Trevor J. Gambell (Eds.), From Seed to Harvest: Looking at Literature, (Ottawa:Canadian Council of Teachers of English, Ian Pringle (General Editor) 1985), 43-49; "Virtual and Actual Forms of Literary Response," Journal of Aesthetic Education, 20(2), (Summer) 1986, 51-57.

${ }^{3}$ See especially Jane Tompkins (Ed.), Reader-Response Criticism: From Formalism to Post-Structuralism (Baltimore and London: The Johns Hopkins University Press, 1980) and Gordon M. Pradl (Ed.), Prospect and Retrospect: Selected Essays of James Britton (London: Heinemann Educational Books; Montclair, N.J.: Boynton/Cook Publishers, Inc., 1982).

${ }^{4}$ Northrop Frye, The Secular Scripture: A Study of the Structure of Romance (Cambridge, Ma.: Harvard University Press, 1976), 131.

5 "'For by some innate power the true sublime uplifts our souls; we are filled with a proud exaltation and a sense of vaulting joy, just as though we had ourselves produced what we had heard." Longinus, "On the Sublime" in T. S. Dorsch (Ed.), Aristotle, Horace, Longinus: Classical Literary Criticism (Harmondsworth, England: Penguin, 1965), 107.

${ }^{6}$ Fredric Jameson, The Political Unconscious: Narrative as a Socially Symbolic Act (Ithaca, N.Y.: Cornell University Press, 1981), 283, 184; George Steiner, Nostalgia for the Absolute: The Massey Lectures (Toronto: CBC Publications, 1974). Quoted from Deanne Bogdan, "Pygmalion as Pedagogue," op. cit., 69.

${ }^{7}$ See Northrop Frye, Fables of Identity: Studies in Poetic Mythology (New York and London: Harcourt, Brace, Jovanovich, 1963), 31.

${ }^{8}$ Deanne Bogdan, "Virtual and Actual Forms of Literary Response," op. cit.

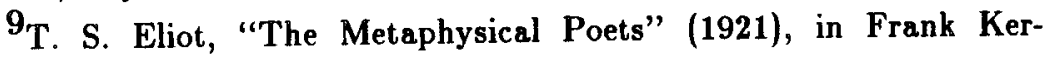


mode (Ed.), Selected Prose of T. S. Eliot (London: Faber and Faber, 1975), 64-65.

10 Northrop Frye, T. S. Eliot (Edinburgh and London: Oliver and Boyd Ltd., 1963), 31, 81-82.

11 Wlad Godzich, "Introduction: Caution! Reader at Work!" in Paul de Man, Blindness and Insight: Essays in the Rhetoric of Contemporary Criticism, Theory and History of Literature, Volume 7 (Minneapolis: University of Minnesota Press, 1971, 1983), xx.

12 Ibid., xx. Cf. Northrop Frye, The Well-Tempered Critic (Bloomington: Indiana University Press, 1963), 145.

$13_{\text {Northrop Frye, The Critical Path: An Essay on the Social }}$ Context of Literary Criticism, (Bloomington: Indiana University Press, 1973), 29.

14 Northrop Frye, Anatomy of Criticism: Four Essays (Princeton, N.J.: Princeton University Press, 1959), 11.

15 Northrop Frye, Fables of Identity, 21.

16 Aristotle, "On the Art of Poetry," in T. S. Dorsch (Ed.), op. cit., 40.

17"The most effective form of discovery is that which is accompanied by reversals, like the one in Oedipus." Aristotle, "On the Art of Poetry," 46. See also Northrop Frye, Fables of Identity, 25.

18 Sinclair Ross, “The Painted Door," in Alec Lucas (Ed.), Great Canadian Short Stories (New York: Dell, 1971), 114-5.

19 Northrop Frye, The Stubborn Structure: Essays on Criticism and Society(London: Methuen and Co., 1970), 77.

20 Aristotle, "On the Art of Poetry," 35.

21 Northrop Frye, A Natural Perspective: The Development of Shakespearian Comedy and Romance (New York: Harcourt, Brace and World, Inc., 1965), 10.

${ }^{22}$ Douglas Vipond and Russell Hunt of St. Thomas University, New Brunswick carried on a separate study with Updike's "A \& P", and found that as a rule, college students dislike the story. We had no knowledge of our mutual research interest in the story, even though our work was done virtually simultaneously. Some of my references to Vipond and Hunt's research are to their unpublished paper, "The Reader, The Text, The Situation: Blocks and Affordances in Literary Reading," which was later incorporated into an article, "Point-Driven Understanding: Pragmatic and Cognitive Dimensions of Literary Reading," Poetics, 13, 1984, 261-277.

${ }^{23}$ Vipond and Hunt make the observation that in order to be point-driven in literary reading, it is necessary that the text be perceived as an "artifact," and that students who read "A \& P" tend 
not to be point-driven. This supports my contention that realism militates against seeing literature separate from life, a perception so necessary to apprehending mythos as dianoia. See Vipond and Hunt, "Point-Driven Understanding: Pragmatic and Cognitive Dimensions of Literary Reading," op. cit., 272.

${ }^{24}$ Deanne Bogdan, "Virtual and Actual Forms of Literary Purpose," The Journal of Aesthetic Education, 54.

25 Northrop Frye, Anatomy of Criticism, 17; The Stubborn Structure, 102; The Well-Tempered Critic, 15.

26 Response in terms of the readily discernible is appropriate to minor fiction, which simply ornaments the commonplace according to Vladimir Nabokov. See "Good Readers and Good Writers," in his Lectures on Literature (New York and London: Harcourt, Brace, Jovanovich, 1980), 2 .

27 John Updike, "A \& P", in his Pigeon Feathers and Other Stories (New York: Alfred A. Knopf, 1962), 187. All references to the story are taken from this edition.

28 I agree with Vipond and Hunt that "types or modes of reading . . . are not characteristics of readers, ... or ...even of whole readings," but of goals and attitudes during the reading process. I use the term "responders" simply as a way of concretizing and personalizing types of response. Vipond and Hunt, "Point-Driven Understanding: Pragmatic and Cognitive Dimensions of Literary Reading," op. cit., 269.

29 While these examples are Vipond's and Hunt's, the categorizations are mine. "The Reader, The Text, The Situation," op. cit. 7 .

30 Deanne Bogdan, "Virtual and Actual Forms of Literary Response," The Journal of Aesthetic Education, 55.

31 Northrop Frye, "Preface," The Myth of Deliverance: Reflections on Shakespeare's Problem Comedies (Toronto: University of Toronto Press, 1983) 1-2.

32 Northrop Frye, The Critical Path, 32.

${ }^{33}$ Vipond and Hunt, "The Reader, The Text, The Situation," op. cit. 11.

${ }^{34}$ See Ronald Sutherland, "The Calvanist-Jansenist Pantomime," in his Second Image: Comparative Studies in Quebec/Canadian Literature (Toronto: New Press, 1971), 60-87.

35، The ideal experience itself ... never occurs, but with intense practice and concentration, a deeply satisfying approximation may occur very rarely." Northrop Frye, The Critical Path, 30-31.

${ }^{36}$ Paul de Man, Blindness and Insight, op. cit. 17. 
37 Aristotle defines "thought" as one of the three objects of imitation: it is what "is related to the arts of politics and rhetoric... (what) is present in speeches where something is being shown to be true or untrue, or where some general opinion is being expressed." We might say it is the set of intellectual and moral assumptions which the reader shares with the author. Aristotle, "On the Art of Poetry," 40-41.

38Plato, "Phaedrus," in Walter Hamilton (Ed. and Trans.), Plato, Phaedrus and the Seventh and Eighth Letters (Harmondsworth, England: Penguin, 1973), 56. 